\title{
Effect of storage on quality features of local onion landrace 'Vatikiotiko'
}

\author{
S.A. Petropoulos ${ }^{1, *}$, Â. Fernandes ${ }^{2}$, L. Barros ${ }^{2}$, J.C.M. Barreira² ${ }^{2}$ I.C.F.R. Ferreira ${ }^{2}$, G. Ntatsi ${ }^{3}$ and \\ V. Antoniadis ${ }^{1}$
}

${ }^{1}$ University of Thessaly, Dept. of Agr., Crop Production and Rural Environment, 38446 N. Ionia, Magnissia, Greece; ${ }^{2}$ Mountain Res. Centre, ESA, Poly. Ins. of Bragança, Campus de Santa Apolónia, 1172, 5301-855 Bragança, Portugal; ${ }^{3}$ Agricultural University of Athens, Dept. of Crop Production, Iera odos 75, 11855 Athens, Greece.

\begin{abstract}
'Vatikiotiko' is a Greek landrace of Allium cepa L. of the Liliaceae family, cultivated only in the region of Vatika, in Lakonia prefecture as a short day onion. The dry bulbs are a quality product highly sought after in Greek market, since this is the earliest onion that comes out during Spring. However, so far the production is limited and the potential of this landrace is not fully developed. In the present study we examined the effect of storage at two temperatures $\left(23 \pm 1\right.$ and $\left.5 \pm 1^{\circ} \mathrm{C}\right)$ and $60-70 \% \mathrm{RH}$ (relative humidity) on marketability and quality features of dry bulbs of 'Vatikiotiko' landrace and 'Sivan $F_{1}$ ' which is also cultivated in the specific region. The experiments were carried out at the University of Thessaly, Greece during the period 2014-2015. The quality features that were recorded during storage included fresh weight loss, bulb firmness, antioxidants and sugar's composition. The measurements were taken at regular intervals and the storage was completed when either bulbs had not marketable quality or sprouting occurred. So far the results have shown that 'Vatikiotiko' onion can be stored for 7 months at both temperatures, whereas at $5 \pm 1^{\circ} \mathrm{C}$ storage could be prolonged for almost 8 months without significant marketability and quality loss. Similarly, 'Sivan $F_{1}$ ' sprouting occurred after 5 and 6 months at $23 \pm 1$ and $5 \pm 1^{\circ} \mathrm{C}$, respectively. Therefore, the fact that 'Vatikiotiko' landrace is a storage onion allows for further valorization in order to increase total production and yield, since the stored product could cover the market needs that arise throughout the year, whereas breeding is needed in order to minimize the genetic variability of the landrace and increase uniformity of the final product.
\end{abstract}

Keywords: Allium cepa, landrace, onion, storage, 'Vatikiotiko' landrace, weight loss

\section{INTRODUCTION}

Onion (Allium cepa L.) is one of the most important vegetable crops with a world annual production of 84.308.184 tonnes of dry bulbs (FAO, 2011), a substantial amount of which has to be stored in storage rooms for long terms in order to cover market needs throughout the year. Consumer acceptance of dry bulbs after storage is highly dependent on their quality. For optimum quality, many factors have to be taken under consideration, including genotype, and preharvest and postharvest conditions. 'Vatikiotiko' onion is a short day onion with high dry matter content (Petropoulos et al., 2015), that makes it preferable for long term storage according to Gubb and MacTavish (2002). The method of curing (field curing or forced air curing), the growing conditions (climate, cultivation practices) and the harvest stage (percentage of fallen tops) can significantly affect the quality of dry bulbs during storage (Downes et al., 2009; Rattin et al., 2011; Eshel et al., 2014), whereas handling after harvest (storage conditions) is a key factor for retaining high quality (Gubb and MacTavish, 2002; Brewster, 2008).

Onion bulbs' quality is affected mostly due to water losses, sprouting, routing and changes in chemical composition during and after storage. According to Adamicki (2005), storage conditions can significantly affect sprouting, rooting and transpiration rate and

*E-mail: spetropoulos@uth.gr 
therefore enhance shelf-life of dry onion bulbs, whereas curing duration, curing method and curing temperature, can affect root growth and quality of bulbs under storage (Downes et al., 2009; Baloch et al., 2012; Eshel et al., 2014). Grevsen and Sorensen (2004) reported that preharvest conditions such as sowing method (transplantation or direct sowing) and stage of harvest (harvest at 20-50\% "top fall down") and genotype could reduce sprouting incidence during or after long-term storage. Storage of dry bulbs can affect chemical composition during storage, since many changes have been reported so far in the literature. Significant differences in glucose and pyruvate content of dry onion bulbs under controlled atmosphere storage, depending on both the cultivar and the bulb section (top, middle and bottom section), have been reported (Abayomi and Terry, 2009). Sharma et al. (2014) reported significant changes in flavonol and sugar contents during long-term storage at different light regimes (dark room and glasshouse storage). Pungency, flavor and sugar content of dry onion bulbs were not affected when stored under controlled atmospheres, whereas storage at $5^{\circ} \mathrm{C}$ or under field conditions decreased soluble solids content and bulb firmness, and increased pungency, pH and flavonols (Coolong et al., 2008; Rodrigues et al., $2010 \mathrm{a}, \mathrm{b}$ ). In contrast, Melo et al. (2012) reported that storage of onion bulbs of 'Optima' at $5 \pm 1^{\circ} \mathrm{C}$ and $85 \pm 5 \%$ RH resulted in an increase of bulb firmness after a period of 60 days.

Carbohydrate content is an essential quality feature since it determines bulb taste. According to Hansen (1999), sugar content decreased during storage, mostly due to increased respiration, which consequently resulted in higher nitrogen and protein content in the dry matter. Moreover, sugar composition depends on storage temperature and duration and is strongly correlated with the end of dormant state and sprouting initiation since sucrose and fructo-oligosaccharide hydrolysis by metabolizing enzymes seems to act as a biochemical signal for sprouting by increasing the levels of fructose due to fructan hydrolysis (Benkeblia et al., 2005). In addition, the antioxidant activity of onion has been reported to decrease, when bulbs are stored at 5 or $25^{\circ} \mathrm{C}$, with high temperatures having a more detrimental effect (Gennaro et al., 2002).

The aim of the present study was to evaluate for the first time the effect of two commercially applied storage conditions on quality features and marketability of local landrace 'Vatikiotiko' in comparison with a commercial genotype. For this reason we stored dry onion bulbs at $5 \pm 1$ and $23 \pm 1^{\circ} \mathrm{C}$ and $60-70 \% \mathrm{RH}$, and evaluated water loss, bulb firmness and sugar's composition for both temperatures.

\section{MATERIALS AND METHODS}

Samples of onions of local landrace 'Vatikiotiko' and 'Sivan $\mathrm{F}_{1}$ ', were collected within the first fortnight of June 2014 (10-15 th of June), directly after curing for 2 weeks. The selected farms are located in Lakonia prefecture ("latitude $36^{\circ} 31^{\prime} 42^{\prime \prime}$, longitude $23^{\circ} 02^{\prime} 51^{\prime \prime}$, $10 \mathrm{~m}$ a.s.l.). Both of the selected genotypes ('Vatikiotiko' and 'Sivan $\mathrm{F}_{1}$ ') are short day onions. After sample collection an assessment of quality features was carried out on June 18, 2014 $\left(\mathrm{t}_{0}\right)$ and then samples from each genotype were stored at two different conditions. The storage conditions were as follows: a) $5 \pm 1^{\circ} \mathrm{C}$ and $60-70 \% \mathrm{RH}$ and b) $23 \pm 1^{\circ} \mathrm{C}$ and $60-70 \% \mathrm{RH}$. During storage, bulb weight was recorded at regular intervals (approximately every 30 days), whereas quality features were recorded twice after the initial measurement. The first measurement was carried out 126 days after storage $\left(t_{1}\right)$, and the second and final measurement $\left(t_{2}\right)$ was carried out 153 to 210 days after storage (depending on genotype and storage conditions). The last measurement was taken when bulbs started to sprout or when marketable quality of bulbs was unacceptable due to severe water losses and very low optical appearance. Free sugars were determined by high performance liquid chromatography coupled to a refraction index detector (HPLC-RI), after an appropriate extraction procedure (Guimarães et al., 2013). The equipment consisted of an integrated system with a pump (Knauer, Smartline system 1000, Berlin, Germany), degasser system (Smartline manager 5000), auto-sampler (AS-2057 Jasco, Easton, MD, USA) and a RI detector (Knauer Smartline 2300, Berlin, Germany). Data were analysed using Clarity 2.4 Software (DataApex, Podohradska, Czech Republic). Sugars identification was made by comparing the relative retention times of sample peaks with standards and quantification was based on the 
RI signal response of each standard, using the internal standard (IS, melezitose) method and by using calibration curves obtained from the commercial standards of each compound. Antioxidant activity was assessed according to the evaluation of free radicals scavenging activity, reducing power and lipid peroxidation inhibition (Roriz et al., 2014). Total phenolics were estimated by Folin-Ciocalteu colorimetric assay according to procedures previously described by Barros et al. (2010). The data from weight loss and bulb firmness were subjected to statistical analysis using the STATGRAPHICS Plus 5.1 logistic package. For chemical composition sampling, onion bulbs were bisected equatorially in order to obtain a section of about $1 \mathrm{~cm}$ height and $10 \mathrm{~g}$ of fresh weight and after removing the outer skin the flesh was cut in small pieces. Three samples were used for each genotype, temperature and storage time and all the assays were carried out in triplicate. An analysis of variance (ANOVA) with type III sums of squares was performed using the GLM (General Linear Model) procedure of the SPSS software. The dependent variables were analysed using 3-way ANOVA, with the factors temperature (T), storage time (ST) and genotype (G). When a statistically significant interaction $(T \times S T, T \times G, S T \times G$ or $T \times S T \times G)$ was detected, the corresponding factors were evaluated simultaneously by the estimated marginal means plots for all levels of each single factor. Alternatively, if no statistical significant interaction was verified, means within each factor were compared using Tukey's honestly significant difference (HSD) multiple comparison test. All the statistical analyses were carried out using SPSS v. 22.0 program (IBM Corp., Armonk, NY, USA). Three samples were analysed for each one of the onion genotypes, whereas all of the assays were carried out in triplicate. The results were expressed as mean values and standard deviation (SD).

\section{RESULTS AND DISCUSSION}

Weight loss is one of the most important factors for onion bulbs during storage, since it determines not only quality but also the final marketable weight and product added value. In our study, storage at $5^{\circ} \mathrm{C}$ resulted in significantly lower weight losses for both genotypes (6.6 and $8.1 \%$ for 'Vatikiotiko' and 'Sivan $\mathrm{F}_{1}$ ', respectively) comparing to $23^{\circ} \mathrm{C}(12.2$ and $14.8 \%$ for 'Vatikiotiko' and 'Sivan $F_{1}$ ', respectively; Figure 1). In addition, final weight losses for 'Vatikiotiko' were significantly lower than those for 'Sivan' for both temperatures, a result which is very important especially when considering that 'Vatikiotiko' was stored at $23^{\circ} \mathrm{C}$ for 57 days more than 'Sivan $F_{1}$ '. Similar results have been reported by Adamicki (2005) and Grevsen and Sorensen (2004) who also reported that storage potential of dry onion bulbs is dependent on storage conditions, whereas Gubb and MacTavish (2002) suggested that apart from storage conditions genotype could also affect storage potential. Bulb firmness decreased significantly during storage, especially for 'Sivan $\mathrm{F}_{1}$ ' where the decrease was up to 40 and $43 \%$ at 5 and $25^{\circ} \mathrm{C}$, respectively (data not shown). For 'Vatikiotiko' onion, the final decrease percentage was similar to that of 'Sivan $\mathrm{F}_{1}$ ', however the bulbs of the former were stored for 57 days more than the latter. In contrast, Melo et al. (2012) reported an increase in bulb firmness after 30 days of storage at $5^{\circ} \mathrm{C}$, whereas Rodriguez et al. $(2010 \mathrm{a}, \mathrm{b})$ reported similar results with the present study. This discrepancy may be due to the storage duration, since Melo et al. (2012) carried out a short-term storage (30 days of storage comparing to 210 days in the present study).

Regarding total sugars content, it was significantly affected by both genotype and storage duration with more profound effect of the genotype, where 'Sivan $\mathrm{F}_{1}$ ' had consistently higher sugars content than 'Vatikiotiko' throughout the storage period (Figure 2). Moreover, sugars content tended to increase when bulbs were stored at $25^{\circ} \mathrm{C}$, mostly due to sprouting initiation of 'Sivan $\mathrm{F}_{1}$ ' bulbs. Fructose content increased only in the case of 'Vatikiotiko' and when bulbs were stored at $5^{\circ} \mathrm{C}$, whereas glucose was not affected by both temperature and genotype (Figures 3 and 4). The increase in fructose content was observed after 126 days $\left(t_{1}\right)$ of storage and then stabilized until the end of storage $\left(t_{2}\right)$. Moreover, Total Soluble Content ( ${ }^{\circ} \mathrm{Brix}$ ) either remained unchanged or slightly decreased during storage, regardless of storage temperature and genotype (data not shown). These results are in agreement with those of Benkeblia et al. (2005) who report an increase in reducing sugars after a long-term storage due to hydrolysis of fructo-oligosaccharides and sprouting 
initiation. Moreover, Yoo et al. (2012) and Abayomi and Terry (2009) reported fluctuations in sucrose and glucose and subsequently in total sugars content throughout a five months storage at $5^{\circ} \mathrm{C}$ under controlled atmospheres, whereas at the end of storage fructose and glucose remained unchanged and total sugars were slightly reduced.

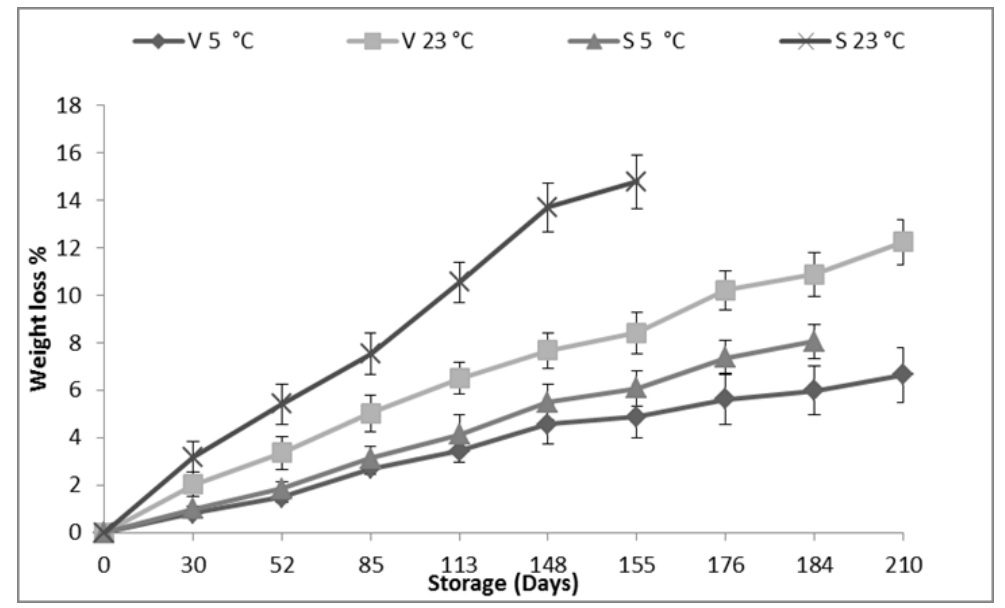

Figure 1. Weight loss (\%) of bulbs in relation to storage time (days) under two storage temperatures. Vertical bars represent Standard Deviation (SD).
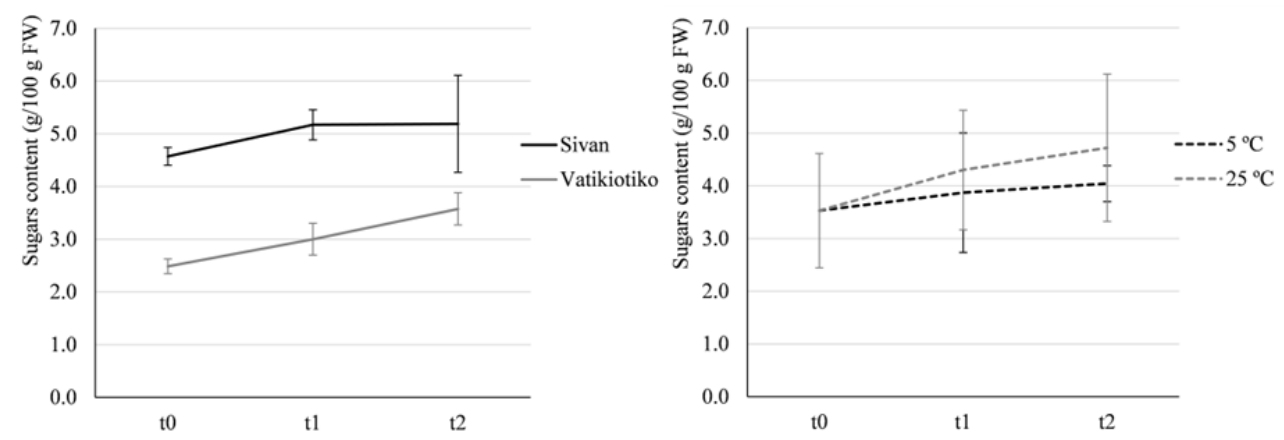

Figure 2. Sugars content (mg $100 \mathrm{~g}^{-1}$ fresh weight) in onion bulbs in relation to a) genotype and $b$ ) storage temperature. ( $\mathrm{t}_{0}$ : day 0 of storage; $\mathrm{t}_{1}: 126$ days after storage, $\mathrm{t}_{2}: 210$ for 'Vatikiotiko' at both temperatures and 182 days $\left(5^{\circ} \mathrm{C}\right)$ and 153 days $\left(25^{\circ} \mathrm{C}\right)$ for 'Sivan $\mathrm{F}_{1}$ ').
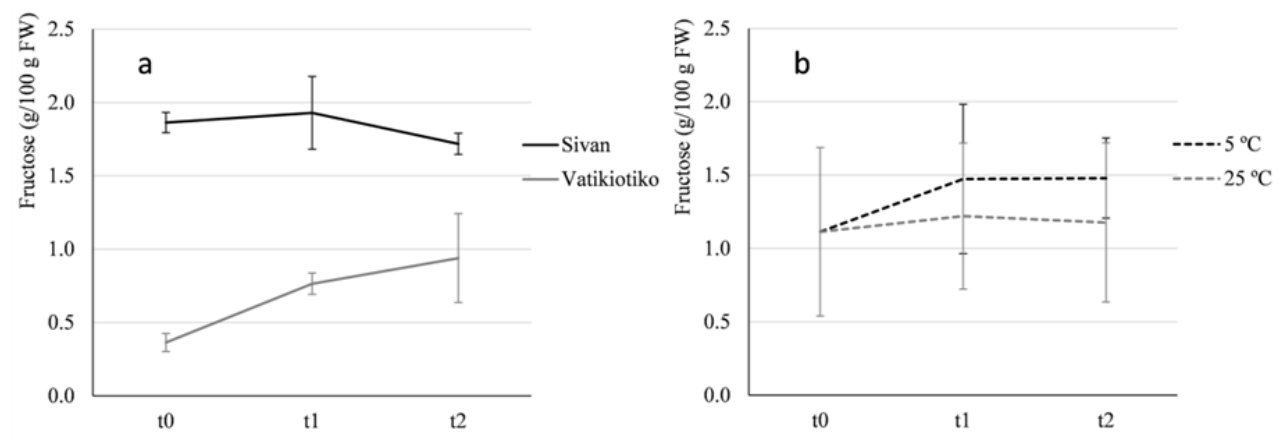

Figure 3. Fructose content (mg $100 \mathrm{~g}^{-1}$ fresh weight) in onion bulbs in relation to a) genotype and $b$ ) storage temperature. ( $t_{0}$ : day 1 of storage; $t_{1}: 126$ days after storage, $\mathrm{t}_{2}: 210$ for 'Vatikiotiko' at both temperatures and 182 days $\left(5^{\circ} \mathrm{C}\right)$ and 153 days $\left(25^{\circ} \mathrm{C}\right)$ for 'Sivan $\mathrm{F}_{1}$ '). 


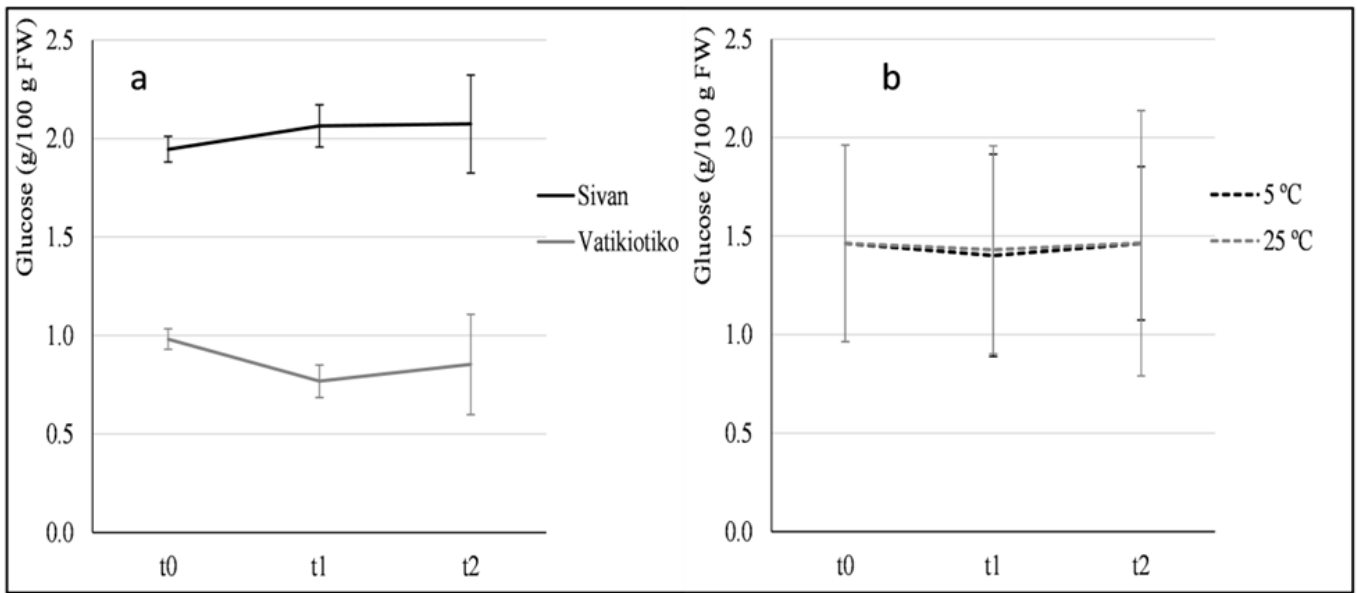

Figure 4. Glucose content in (mg $100 \mathrm{~g}^{-1}$ fresh weight) onion bulbs in relation to a) genotype and $b$ ) storage temperature. ( $t_{0}$ : day 0 of storage; $t_{1}$ : 126 days after storage, $\mathrm{t}_{2}: 210$ for 'Vatikiotiko' at both temperatures and 182 days $\left(5^{\circ} \mathrm{C}\right)$ and 153 days $\left(25^{\circ} \mathrm{C}\right)$ for 'Sivan $\mathrm{F}_{1}$ ').

Antioxidant activity was favored by storage at $25^{\circ} \mathrm{C}$, with a gradual increase during storage (Figure 5). In contrast, Gennaro et al. (2002) reported a decrease in antioxidant activity of 'Tropea Red' onion, however they conducted analysis in the whole edible portion of bulbs in order to simulate domestic use, which can significantly affect results, since antioxidant activity depends on bulb section (Downes et al., 2009). Total phenols decreased significantly after 126 days of storage $\left(t_{1}\right)$, regardless of temperature, whereas 'Sivan $F_{1}$ ' was more susceptible to phenols' decrease than 'Vatikiotiko' where no significant changes were observed (Figure 6). Benkeblia (2000) have also reported similar trends in total phenols content during storage at 4 and $20^{\circ} \mathrm{C}$, suggesting an inverse correlation of phenolics and sprouting incidence and a linkage with phenylalanine amonia-lyase (PAL) enzyme activity.

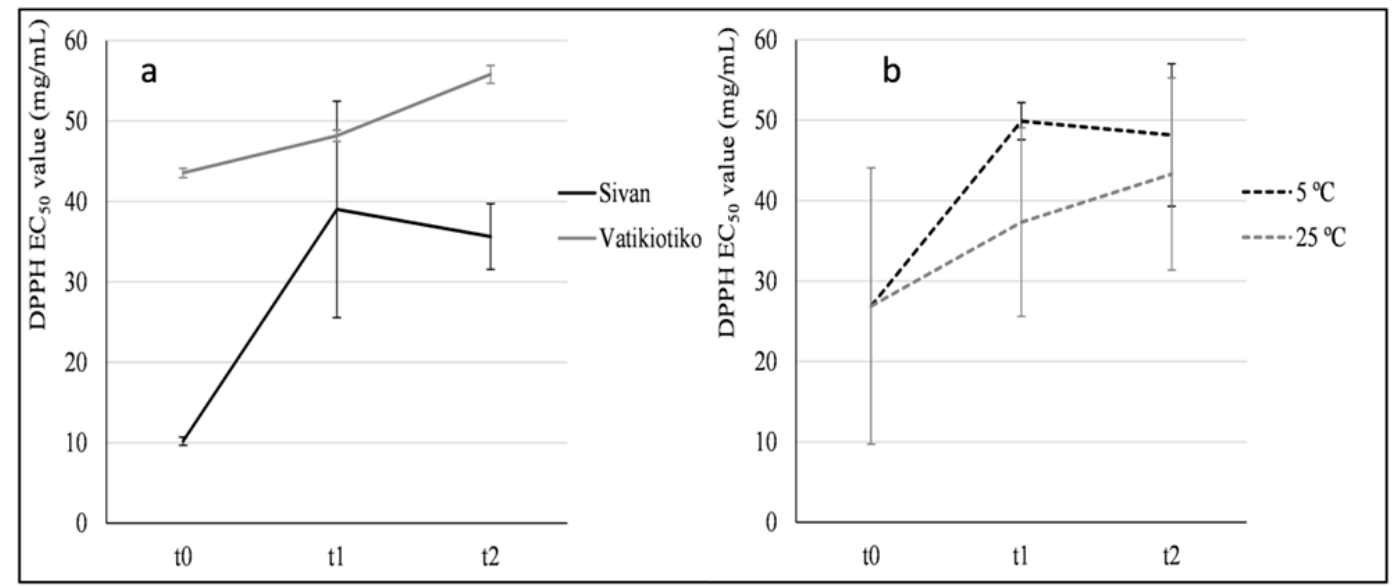

Figure 5. DPPH $\mathrm{EC}_{50}$ values ( $\mathrm{mg} \mathrm{mL}^{-1}$ ) of onion bulbs in relation to a) genotype and b) storage temperature. ( $\mathrm{t}_{0}$ : day 0 of storage; $\mathrm{t}_{1}: 126$ days after storage, $\mathrm{t}_{2}: 210$ for 'Vatikiotiko' at both temperatures and 182 days $\left(5^{\circ} \mathrm{C}\right)$ and 153 days $\left(25^{\circ} \mathrm{C}\right)$ for 'Sivan $\mathrm{F}_{1}$ '). 


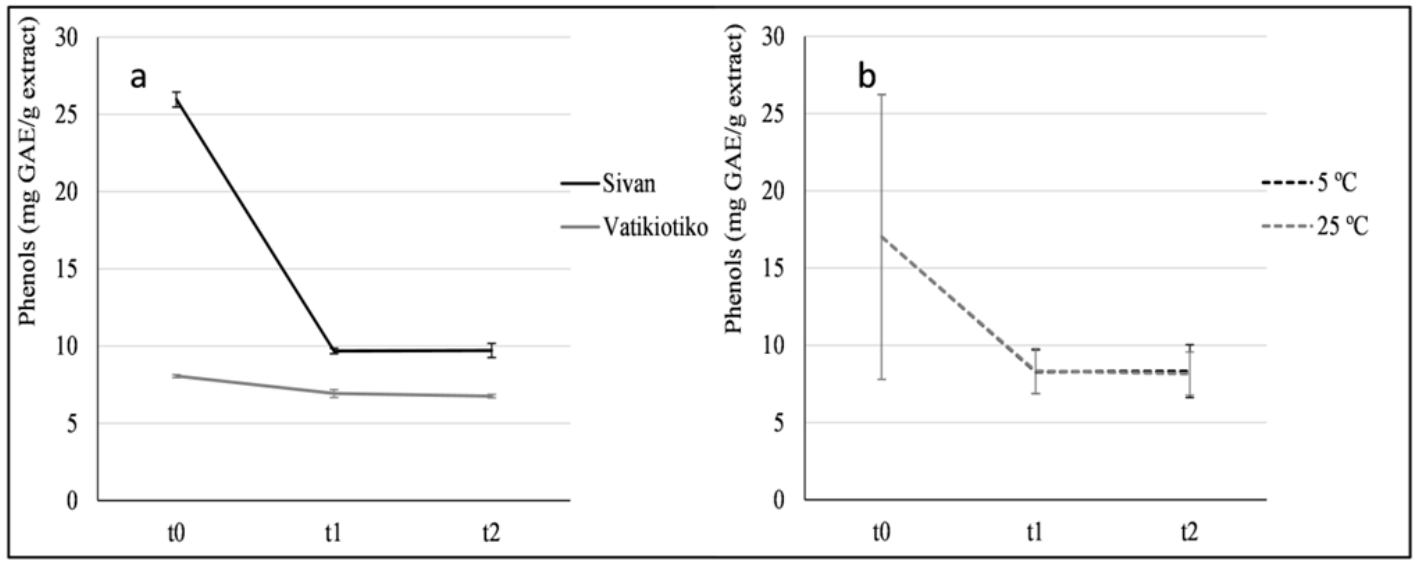

Figure 6. Total phenols of onion bulbs in relation to a) genotype and b) storage temperature ( $t_{0}$ : day 0 of storage; $t_{1}: 126$ days after storage, $t_{2}: 210$ for 'Vatikiotiko' at both temperatures and 182 days $\left(5^{\circ} \mathrm{C}\right)$ and 153 days $\left(25^{\circ} \mathrm{C}\right)$ for 'Sivan $F_{1}$ ').

\section{CONCLUSIONS}

From the results of the present study it could be concluded that 'Vatikiotiko' onion landrace is ideal for long-term storage, since weight-loss percentage and quality features such as sugars content, are not severely affected, especially when storage is made under low temperatures $\left(5^{\circ} \mathrm{C}\right)$. Therefore, this feature should be valorized by encouraging cultivation of this landrace and engaging more farmers in order to increase total production and cover market needs throughout the year.

\section{ACKNOWLEDGMENTS}

This research was co-financed by the Rural Development Program of Greece 20072013, Axis 4, Submeasure 421a, National Cooperation Project entitled "Finest Greek Tastes" and Portuguese Foundation for Science and Technology (FCT) through PestOE/AGR/UI0690/2011).

\section{Literature cited}

Abayomi, L.A., and Terry, L.A. (2009). Implications of spatial and temporal changes in concentration of pyruvate and glucose in onion (Allium cepa L.) bulbs during controlled atmosphere storage. J. Sci. Food Agric. 89 (4), $683-$ 687.

Adamicki, F. (2005). Effects of pre-harvest treatments and storage conditions on quality and shelf-life of onions. Acta Hortic. 688, 229-238 http://dx.doi.org/10.17660/ActaHortic.2005.688.31.

Baloch, J.-U.-D., Baloch, S., Munir, M., and Alizai, A.A. (2012). A study on root growth of onion (Allium cepa L.) under storage conditions. Pakistan J. Life Soc. Sci. 10 (2), 156-160.

Barros, L., Oliveira, S., Carvalho, A.M., and Ferreira, I.C.F.R. (2010). In vitro antioxidant properties and characterization in nutrients and phytochemicals of six medicinal plants from the Portuguese folk medicine. Ind. Crops Prod. 32 (3), 572-579.

Benkeblia, N. (2000). Phenylalanine ammonia-lyase, peroxidase, pyruvic acid and total phenolics variations in onion bulbs during long-term storage. LWT -. Food Sci. Technol. (Campinas) 33 (2), 112-116.

Benkeblia, N., Ueno, K., Onodera, S., and Shiomi, N. (2005). Variation of fructooligosaccharides and their metabolizing enzymes in onion bulb (Allium cepa L. cv. Tenshin) during long-term storage. J. Food Sci. 70 (3), 208-214.

Brewster, J.L. (2008). Onions and other vegetable alliums (Wallingford, UK: CAB International).

Coolong, T.W., Randle, W.M., and Wicker, L. (2008). Structural and chemical differences in the cell wall regions in relation to scale firmness of three onion (Allium cepa L.) selections at harvest and during storage. J. Sci. Food Agric. 88 (7), 1277-1286. 
Downes, K., Chope, G.A., and Terry, L.A. (2009). Effect of curing at different temperatures on biochemical composition of onion (Allium cepa L.) skin from three freshly cured and cold stored UK-grown onion cultivars. Postharvest Biol. Technol. 54 (2), 80-86.

Eshel, D., Tepper-Bamnolker, P., Vinokur, Y., Saad, I., and Zutahy, Y. (2014). Fast-curing: a method to improve postharvest quality of onions in hot climate harvest. Postharvest Biol. Technol. 88, 34-39 http://dx.doi.org/10.1016/j.postharvbio.2013.09.002.

Food and Agricultural Organization. (2011). www.fao.org.

Gennaro, L., Leonardi, C., Esposito, F., Salucci, M., Maiani, G., Quaglia, G., and Fogliano, V. (2002). Flavonoid and carbohydrate contents in Tropea red onions: effects of homelike peeling and storage. J. Agric. Food Chem. 50 (7), 1904-1910.

Grevsen, K., and Sorensen, J.N. (2004). Sprouting and yield in bulb onions (Allium cepa L.) as influenced by cultivar, plant establishment methods, maturity at harvest and storage conditions. J. Hortic. Sci. Biotechnol. 79 (6), 877-884.

Gubb, I.R., and MacTavish, H.S. (2002). Onion pre- and post-harvest considerations. In Allium Crop Sciences: Recent Advances, H.D. Rabinowitch and L. Currah eds. (Wallingford, UK: CAB International), p.233-266.

Guimarães, R., Barros, L., Dueñas, M., Calhelha, R.C., Carvalho, A.M., Santos-Buelga, C., Queiroz, M.J.R.P., and Ferreira, I.C.F.R. (2013). Nutrients, phytochemicals and bioactivity of wild Roman chamomile: a comparison between the herb and its preparations. Food Chem 136 (2), 718-725.

Hansen, S.L. (1999). Content and composition of dry matter in onion (Allium cepa) as influenced by their developmental stage at time of harvest, and long-term storage. Acta Agr. Scand. B-S. 49, 103-109.

Melo, C.O., Moretti, C.L., Machado, C.M.M., Mattos, L.M., and Muniz, L.B. (2012). Chemical and physical alterations in storaged onion genotypes under refrigeration. Cienc. Rural 42, 2078-2084 http://dx.doi.org/10.1590/S010384782012001100027

Petropoulos, S.A., Fernandes, Â., Barros, L., Ferreira, I.C.F.R., and Ntatsi, G. (2015). Morphological, nutritional and chemical description of "Vatikiotiko", an onion local landrace from Greece. Food Chem 182, 156-163. PubMed http://dx.doi.org/10.1016/j.foodchem.2015.03.002

Rattin, J.E., Assuero, S.G., Sasso, G.A., and Tognetti, J.A. (2011). Accelerated storage losses in onion subjected to water deficit during bulb filling. Sci. Hortic. (Amsterdam) 130 (1), 25-31.

Rodrigues, A.S., Pérez-Gregorio, M.R., García-Falcón, M.S., Simal-Gándara, J., and Almeida, D.P.F. (2010a). Effect of post-harvest practices on flavonoid content of red and white onion cultivars. Food Contr. 21 (6), 878-884.

Rodrigues, A.S., Almeida, D.P.F., García-Falcón, M.S., Simal-Gándara, J., and Pérez-Gregorio, M.R. (2010b). Postharvest storage systems affect phytochemical content and quality of traditional Portuguese onion cultivars. Acta Hortic. 934, 1327-1334. http://dx.doi.org/10.17660/ActaHortic.2012.934.180

Roriz, C.L., Barros, L., Carvalho, A.M., Santos-Buelga, C., and Ferreira, I.C.F.R. (2014). Pterospartum tridentatum, Gomphrena globosa and Cymbopogon citratus: A phytochemical study focused on antioxidant compounds. Food Res. Int. 62, 684-693 http://dx.doi.org/10.1016/j.foodres.2014.04.036.

Sharma, K., Asnin, L., Ko, E.Y., Lee, E.T., and Park, S.W. (2014). Phytochemical composition of onion during longterm storage. Acta Agr. Scand. B-S. 65, 150-160.

Yoo, K.S., Lee, E.J., and Patil, B.S. (2012). Changes in flavor precursors, pungency and sugar content in short-day onion bulbs during 5-month storage at various temperatures or in controlled atmospheres. J. Food Sci. 77 (2), 216-221. 
